\title{
Progesterone and conceptus-derived factors important for conceptus survival and growth
}

\author{
P. Lonergan ${ }^{1,4}$, N. Forde ${ }^{2}$, T.E. Spencer ${ }^{3}$ \\ ${ }^{1}$ School of Agriculture and Food Science, Belfield, Ireland. \\ ${ }^{2}$ Division of Reproduction and Early Development, Leeds Institute of Cardiovascular and Molecular Medicine, \\ University of Leeds, Clarendon Way, Leeds, UK. \\ ${ }^{3}$ Division of Animal Sciences, University of Missouri, Columbia, USA.
}

\begin{abstract}
Progesterone (P4) from the corpus luteum (CL) is critical for the establishment and maintenance of pregnancy and plays a major role in regulating endometrial secretions essential for stimulating and mediating changes in conceptus growth and differentiation throughout early pregnancy in ruminants. Numerous studies have demonstrated an association between elevated P4 and acceleration in conceptus elongation. A combination of in vivo and in vitro experiments found that the effects of $\mathrm{P} 4$ on conceptus elongation are indirect and mediated through P4induced effects in the endometrium. Despite effects on elongation, data on the impact of post-insemination supplementation of $\mathrm{P} 4$ on pregnancy rates are conflicting and typically only result in a modest improvement, if any, in fertility. Differences in conceptus length on the same day of gestation would suggest that factors intrinsic to the blastocysts transferred regulate development, at least in part, and would be consistent with the hypothesis that the quality of the oocyte regulates developmental competence. This paper will review recent knowledge on the effect of P4 on conceptus development in cattle and summarize strategies that have been undertaken to manipulate post fertilization P4 concentrations to increase fertility.
\end{abstract}

Keywords: cattle, conceptus, embryo, pregnancy, progesterone.

\section{Introduction}

Most embryonic loss in cattle occurs in the first few weeks after conception. Fertilisation success is typically high $(\sim 90 \%)$ but a significant proportion of the resulting embryos fail to develop to term. The majority of these embryos are lost between fertilisation and maternal recognition of pregnancy, which in cattle occurs around day 16 post-mating (Diskin and Morris, 2008; Wiltbank et al., 2016). Wiltbank et al. (2016) described four pivotal periods for pregnancy loss during the first trimester of gestation and discussed possible causes for pregnancy failure during these periods. Despite a relatively high fertilization rate $(>85 \%), 20$ $50 \%$ of high-producing lactating dairy cows experience pregnancy loss during the first week of gestation. From days 8 to 27 , concomitant with embryo elongation and maternal recognition of pregnancy, losses average approximately $30 \%$. From days 28 to 60 , losses of approximately $12 \%$ occur while in the fourth period, during the third month of pregnancy, pregnancy losses are reduced (approximately $2 \%$ ), but may be elevated in some cows, particularly in those carrying twins in the same uterine horn (Wiltbank et al., 2016).

Optimal dialogue between the developing embryo and its mother is essential for successful pregnancy recognition and maintenance of pregnancy during the critical peri-implantation period of pregnancy when the stage is set for implantation and placentation that precedes fetal development (Guillomot, 1995; Hue et al., 2012; Spencer et al., 2015). However, this dialogue really only becomes absolutely essential as the time of pregnancy recognition approaches as evidenced by the fact that embryos are routinely transferred to a synchronous uterus up to about day 8 of development in commercial embryo transfer with good success. Indeed, pregnancies have been achieved following transfer of embryos as late as day 16 (Betteridge et al., 1980), although due to the filamentous nature by that time, it is impractical to do so.

Uterine epithelial cells secrete and/or transport a wide range of molecules, including nutrients, collectively referred to as histotroph that are transported into the fetal-placental vascular system to support growth and development of the conceptus (embryo/fetus and associated membranes). In turn, molecules secreted by conceptuses, in particular interferon tau (IFNT), the maternal recognition of pregnancy signal in ruminants, but also prostaglandins (PGs; Dorniak et al., 2011, 2012; Spencer et al., 2013), induce changes in the uterine endometrium which are essential if pregnancy is to be maintained.

There is a strong positive association between the post-ovulatory rise in concentrations of progesterone (P4) and embryonic development in sheep and cattle (Satterfield et al., 2006; Carter et al., 2008). Much has been written about the role of $\mathrm{P} 4$ in the establishment and maintenance of pregnancy. Many researchers have tried to manipulate $\mathrm{P} 4$ concentrations during the first two weeks after mating in an attempt to achieve higher pregnancy rates. Rather than repeat in detail what has already been written, the reader is directed to several other recent comprehensive reviews on the subject (Lonergan, 2011, 2015; Wiltbank et al., 2014; Spencer et al., 2015).

\section{Establishment of pregnancy in cattle}

Following fertilization in the oviduct, the early

\footnotetext{
${ }^{4}$ Corresponding author: pat.lonergan@ucd.ie

Phone: +353(1)601-2147

Received: July 4, 2016

Accepted: July 11, 2016
} 
embryo undergoes the first mitotic cleavage divisions before entering the uterus at about the 16-cell stage on approximately day 4 after ovulation. It soon forms a morula and, by day 7, a blastocyst containing an inner cell mass and a single layer of trophectoderm surrounding a fluid-filled blastocoel cavity. After hatching from the zona pellucida on approximately days 8 to 9 , the spherical blastocyst grows and changes in morphology from a spherical to ovoid shape during a transitory phase preceding the elongation of the trophectoderm to a filamentous form that usually begins between days 12 and 14. The conceptus continues to grow and secrete IFNT, which prevents prostaglandininduced luteolysis and maintains the pregnancy. Unlike primate and rodent embryos which invade the endometrium soon after hatching, ruminant conceptuses do not invade the endometrium during implantation, which commences at approximately day 19 in cattle (Guillomot, 1995), but rather undergo an extended free-floating period of development during which they exibit rapid elongtion of the extraembryonic tissues.

In vitro fertilization studies have demonstrated that contact with the female reproductive tract is not necessary in order for the embryo to reach the hatched blastocyst stage. However, the characteristic elongation of the conceptus prior to implantation is dependent on secretions from the uterus. This elongation does not occur in vitro (Flechon et al., 1986) and does not occur in vivo in the absence of uterine glands (Gray et al., 2002; Spencer and Gray, 2006). Several authors have attempted to induce elongation in vitro by growing blastocysts in confined spaces (Brandão et al., 2004; Alexopoulos et al., 2005; Zhao et al., 2015) but while lateral expansion occurs, events as they occur in vivo are not recapitulated.

Thus, exposure to the uterine environment is required for conceptus elongation. Uterine luminal fluid (ULF) contains embryotrophic substances, collectively termed histotroph, that drive elongation of the conceptus via effects on trophectoderm proliferation and migration as well as attachment and adhesion to the endometrial luminal epithelium (LE; Gray et al., 2001; Spencer et al., 2008; Bazer et al., 2010; Forde et al., 2014a). The ULF is derived primarily from transport and (or) synthesis and secretion of substances by the endometrial LE and glandular epithelium (GE), but also by the conceptus (Forde et al., 2015), and it is a complex and rather undefined mixture of proteins, lipids, amino acids, sugars (glucose, fructose), ions, and exosomes/microvesicles (Bazer, 1975; Gray et al., 2001; Bazer et al., 2012; Burns et al., 2014; Forde et al., $2014 b)$. P4 induces the expression of a number of genes in the endometrial epithelium that are then further stimulated by factors from the conceptus (e.g., IFNT and PGs) and the endometrium itself (Dorniak et al., 2013; Brooks et al., 2014; Lonergan and Forde, 2014). In turn, the genes and functions regulated by these hormones and factors in the endometrial epithelia cause specific changes in the uterine histotroph that govern conceptus survival and elongation (Faulkner et al., 2013; Forde et al., 2014a, 2015).

\section{Progesterone and the endometrium}

A prerequisite for establishing uterine receptivity to implantation in all species studied thus far is loss of expression of $\mathrm{P} 4$ receptors (PGR) from uterine LE and then GE (Bazer et al., 2010). Paradoxically, it is sustained exposure of the endometrium to circulating concentrations of $\mathrm{P} 4$ that leads to this down-regulation of PGR as the luteal phase of the estrous cycle progresses. The concentrations of $\mathrm{P} 4$ in circulation modify the loss of expression of PGR in the endometrium such that, in animals in which $\mathrm{P} 4$ is high there is early loss of the PGR (Okumu et al., 2010) i.e. uterine receptivity to implantation is established earlier. Conversely, low or sub-optimal concentrations of P4 delay loss of the PGR and thus delay establishing uterine receptivity to implantation (Forde et al., 2011a). Thus, in simple terms, it would appear that elevating P4 immediately after estrus or mating simply advances the changes in endometrial gene expression which normally occur (Forde et al., 2009).

The transcriptome of the bovine endometrium has been described under a variety of physiological and experimental conditions (Forde et al., 2009, 2011a, b; Sandra et al., 2011; Bauersachs et al., 2012; Binelli et $a l ., 2015)$. Temporal changes in gene expression in the uterus occur irrespective of whether the cow is pregnant or not and it is really only at the time of maternal recognition of pregnancy at around day 16 that major changes in gene expression between pregnant and cyclic endometrium are detectable (Forde et al., 2011b; Bauersachs et al., 2012). Forde et al. (2009) described the global transcriptome of the endometrium from day 5 to day 16 in pregnant and cyclic cattle under conditions of normal and elevated P4 and revealed how circulating concentrations of $\mathrm{P} 4$ regulate endometrial genes. This study found that P4 supplementation advanced the normal temporal changes in endometrial gene expression, particularly for genes associated with energy sources or contributors to histotroph, which may contribute to advanced conceptus development on day 13 and day 16.

\section{Progesterone and conceptus elongation}

Elongation of the ruminant conceptus is essential for normal pregnancy recognition and implantation. Mamo et al. (2011) described the global transcriptome profile of the bovine conceptus at five key stages of its pre- and peri-implantation growth (days 7, 10, 13, 16, and 19). Analysis identified differentially regulated genes organized in nine gene clusters forming a sequential transcript dynamics across these developmental stages. These data have been expanded upon by more recent studies (Valour et al., 2014; Barnwell et al., 2015, 2016; Ribeiro et al., 2016a, b).

Flechon et al. (1986) cut day 12 ovine blastocysts into pieces and cultured them in vitro for 24 $\mathrm{h}$, to produce structures called trophoblastic vesicles (TV, blastocysts without the embryonic disc). Such TV survived in vitro for up to 10 days but failed to elongate. In contrast, TVs elongated in vivo after transfer to 
recipients demonstrating that trophoblast elongation does not depend necessarily on the presence of the embryo proper, but can occur in TV composed only of the trophectoderm and the extraembryonic endoderm.

Earlier studies in ewes (Wilmut and Sales, 1981; Lawson and Cahill, 1983) and cows (Garrett et al., 1988b) suggested that maternal P4 regulates early conceptus growth and development. More recent studies have confirmed those findings and began to unravel the underlying biology. In particular, significant progress has been made in clarifying the role of P4 in the successful establishment of pregnancy in sheep and cattle, with particular emphasis on how P4 affects endometrial gene expression and conceptus elongation.

The stimulatory effect of $\mathrm{P} 4$ on trophoblast elongation is unequivocal. As mentioned earlier, however, this effect is likely a result of downstream effects of P4-induced changes in gene expression in cells of the endometrium (Satterfield et al., 2006; Forde et al., 2009, 2011a) resulting in changes in the composition of ULF or histotroph to which the developing embryo is exposed (Faulkner et al., 2013). Whether any of the effects of P4 are directly on the embryo has been assessed by experiments in which $\mathrm{P} 4$ was added to medium during the in vitro culture of embryos. Results of such studies have been varied and contradictory with some authors reporting positive effects of P4 (Ferguson et al., 2005, 2011; Merlo et al., 2007) while others have reported no effect (Reggio et al., 1997; Goff and Smith, 1998). Overall, however, despite the presence of PGR mRNA on embryos (Clemente et al., 2009), there is little convincing evidence that $\mathrm{P} 4$ has a direct effect on the early embryo. In our own laboratory, culture of embryos in vitro in the presence of P4 did not affect the proportion developing to the blastocyst stage in the presence or absence of oviductal epithelial cells (Clemente et al., 2009). This finding is consistent with the observations of Larson et al. (2011) who failed to observe a direct effect of P4 either from days 1 to 3 or 4 to 7 after fertilisation. Furthermore, addition of P4 to culture medium had no effect on conceptus elongation after transfer to synchronised recipients (Clemente et al., 2009). In two other in vivo studies, we failed to demonstrate an effect of elevated P4 on blastocyst development. In the study of Carter et al. (2008), no differences in embryonic development on day 5 or day 7 were observed when beef heifers were supplemented with exogenous P4 from day 3, despite dramatic effects on post-hatching elongation between days 13 and 16 of pregnancy. In a follow-up study, multiple in vitro produced embryos were transferred to the oviduct of beef heifers that did or did not receive a $\mathrm{P} 4$ insert on day 3 after onset of oestrus. There was no effect of P4 on the proportion of embryos that developed to the blastocyst stage by day 7 (Carter et al., 2010).

The effects of elevated P4 shortly after conception on the advancement of conceptus elongation have been convincingly demonstrated in cattle and sheep. Garrett et al. (1988b) administered $100 \mathrm{mg}$ P4 on days $1,2,3$ and 4 of pregnancy which increased concentrations of $\mathrm{P} 4$ in peripheral plasma on days 2 to 5 and significantly larger conceptuses on day 14 . Using a P4 implant on day 3 of pregnancy, Carter et al. (2008) significantly elevated concentrations of P4 in plasma until day 8 and this was associated with larger conceptuses recovered at slaughter on day 16. Similarly, when ewes received daily injections of $25 \mathrm{mg}$ P 4 from $36 \mathrm{~h}$ post-mating, blastocyst diameter increased by $220 \%$ on day 9 and at the time of initiation of elongation of blastocysts to a filamentous conceptus on day 12 was advanced (Satterfield et al., 2006); these effects of P4 treatment on blastocyst development were blocked by administration of RU486, a PGR antagonist.

As mentioned above, using a combination of in vitro embryo production and in vivo embryo transfer techniques, we have shown that the effect of P4 on conceptus development is mediated exclusively via the endometrium (Clemente et al., 2009). Interestingly, the embryo does not need to be present in the uterus during the period of $\mathrm{P} 4$ elevation in order to benefit from it (Clemente et al., 2009), strongly suggesting that the effect of P4 is via advancement of the normal temporal changes that occur in the endometrial transcriptome (Forde et al., 2009) resulting in advanced conceptus elongation. In addition, reducing the output of $\mathrm{P} 4$ from the $\mathrm{CL}$, for example, by treatment with prostaglandin F2 $\alpha$ (Beltman et al., 2009b; Forde et al., 2011a, 2012) or by aspirating the contents of the preovulatory follicle just before the expected time of ovulation (O'Hara et al., 2012) results in a delay in the temporal changes in the endometrial transcriptome resulting in delayed conceptus elongation in vivo.

Barnwell et al. (2015) examined the effect of embryo source (in vitro vs. in vivo derived) and recipient $\mathrm{P} 4$ concentration at the time of embryo transfer on conceptus development on day 17. They reported no relationship between $\mathrm{P} 4$ concentration on day 7 at the time of embryo transfer and conceptus length on day 17 . Strangely, when only longer conceptuses were considered, heifers with in vitro produced embryos had lower P4 than those with in vivo derived embryos. In contrast, Frade et al. (2014) reported that higher plasma P4 concentration at timed embryo transfer was associated with increased pregnancy rate in in vitroproduced embryo recipients.

\section{Asynchronous embryo transfer}

The regulatory effect of the uterus on bovine conceptus development, and the role played by $\mathrm{P} 4$, has been beautifully illustrated in studies comparing the outcome of synchronous and asynchronous embryo transfer. Such synchrony between the needs of the developing embryo and uterine secretions has long been recognized as being critical to the successful establishment of pregnancy (Pope, 1988). Indeed, embryo transfer studies in sheep and cattle have clearly demonstrated a need for close synchrony between embryo and the uterine environment of the recipient. Previous studies have established that pregnancy rates are reduced when embryos are greater than $48 \mathrm{~h}$ from synchrony with the recipient's uterine environment (Moore and Shelton, 1964; Rowson and Moor, 1966; 
Rowson et al., 1972).

Asynchronous transfer of day 7 bovine blastocysts to the uteri of day 5 or day 9 recipients resulted in retarded $(5.4 \pm 0.4 \mathrm{~mm})$ or advanced $(50.4 \pm$ $5.2 \mathrm{~mm}$ ) conceptuses on day 14 , respectively, compared to synchronous controls (day 7 to day $7: 15.7 \pm 1.5 \mathrm{~mm}$ ) or conceptuses derived from AI $(12.0 \pm 3.3 \mathrm{~mm}$; Ledgard et al., 2012). Consistent with these observations, Geisert et al. (1991) reported that only 1 of $21(4.8 \%)$ day 8 bovine blastocysts transferred to a day 5 uterus established pregnancy compared to $50 \%$ in synchronous controls.

Administration of P4 early in the estrous cycle of the recipient has been shown in some cases to effectively advance uterine receptivity for the transfer of older asynchronous embryos. In sheep, day 6 recipients after early exposure to exogenous P4, supported development of transferred day 10 blastocysts (Lawson and Cahill, 1983). In cattle, embryo transfer to P4treated recipients $(100 \mathrm{mg} /$ day from day 1 to day 4$)$ which showed estrus $72 \mathrm{~h}$ after the donor cows (i.e., day 8 blastocysts transferred into a day 5 uterus) resulted in pregnancy rates at day 35 similar to those of synchronous $( \pm 12 \mathrm{~h})$ recipients $(42.1 \mathrm{vs} .50 \%)$, while, as mentioned above, only approximately $5 \%$ of day 5 asynchronous recipients became pregnant (Geisert et al., 1991).

Similar data have been reported recently by Randi et al. (2015) who transferred multiple day 7 bovine blastocysts to synchronous (day 7) or asynchronous (day 5 or day 9 ) recipients $(n=10$ per recipient). Transfer of day 7 blastocysts to a day 5 uterus resulted in fewer conceptuses surviving $(20 \%)$ and delayed elongation in those that were recovered. In contrast, transfer to an advanced day 9 uterine environment resulted in the same level of survival as synchronous controls $(\sim 50 \%)$, but conceptus elongation was markedly advanced, in agreement with the observations of (Ledgard et al., 2012). Supplementation of day 5 recipients with $\mathrm{P} 4$ from day 3 increased circulating concentrations of $\mathrm{P} 4$ and increased conceptus length compared to day 5 controls; however, supplementation with $\mathrm{P} 4$ reduced the length of estrous cycles in approximately $50 \%$ of heifers.

Together, these studies indicate that P4 stimulates changes within the uterine environment which regulate receptivity and promote embryo survival and conceptus elongation. Manipulating P4 may be one way of strategically regulating the temporal changes that normally occur in the uterine environment in order to allow flexibility in the timing of embryo transfer. Given the above results indicating that transfer to an advanced uterus (i.e., uterus ahead of the embryo), which has had longer exposure to P4 results in an advancement in conceptus elongation and that such advanced conceptuses produce more IFNT (Kerbler et al., 1997; Rizos et al., 2012), one could reasonably hypothesize that transfer to an advanced uterus would result in improved pregnancy rates. However, interrogation of data from commercial embryo transfer operations does not support that hypothesis (Wright, 1981; Donaldson, 1985; Hasler et al., 1987; Heyman,
1988; Hasler, 2001; Rodrigues et al., 2003; Randi et al., 2015). For example, in the study of Randi et al. (2015), 4749 recipients received a single in vitro produced fresh blastocyst. Overall pregnancy rate was $43.5 \%$, which is about the norm in such commercial IVF operations. Transfer of a day 7 blastocyst to a synchronous day 7 uterus resulted in a pregnancy rate of $47.3 \%$. Transfer to a uterus one day behind (day 6: 46.6\%) did not affect pregnancy rate. However, transfer to a day $5(40.8 \%)$ or a day $8(41.3 \%)$ uterus moderately impacted pregnancy rate while transfer to a uterus 2 days in advance (day 9: $24.4 \%$ ) or 3 days behind (day $4: 27.0 \%$ ) dramatically reduced pregnancy rates compared to results from synchronous transfer of blastocysts. Taking results of all of these studies together, it is clear that the accelerated conceptus elongation associated with transfer of a blastocyst to an advanced uterus does not necessarily translate into an improved pregnancy rate; rather, once synchrony is exceeded by approximately $48 \mathrm{~h}$, pregnancy rates decline appreciably.

\section{Supplementation of progesterone and pregnancy rate}

Results of several retrospective studies have indicated a positive relationship between circulating concentrations of $\mathrm{P} 4$ in the week after breeding and subsequent pregnancy rate (Stronge et al., 2005; Diskin et al., 2006; Parr et al., 2012). Interestingly, there is both a linear and quadratic component to this relationship; that is, too much $\mathrm{P} 4$ may lead to a decline in pregnancy rate. Thus, both sub-and supra-optimal concentrations of $\mathrm{P} 4$ from days 4 to 7 after AI or a suboptimal rate of increase in the concentration of $\mathrm{P} 4$ during this interval are negatively associated with embryonic survival. Cummins et al. (2012) reported that circulating concentrations of P4 were $34 \%$ greater in cows with similar genetic merit for milk production traits, but with extremes of good (Fert+) or poor (Fert-) genetic merit for fertility traits. In a follow-up study, Moore et al. (2014) investigated the factors affecting circulating concentrations of $\mathrm{P} 4$ in those cows. Concentrations of P4 were measured from days 1 to 13 . CL volume was $41 \%$ greater and mean circulating concentrations of $\mathrm{P} 4$ were $79 \%$ greater in Fert + cows compared with Fert- cows. The results indicate that greater circulating concentrations of $\mathrm{P} 4$ were primarily due to a greater capacity of CL to secrete $\mathrm{P} 4$ rather than differences in clearance rate of P4 in this lactating cow genetic model of fertility.

Ultimately, circulating concentrations of $\mathrm{P} 4$ are determined by the balance between the rate of $\mathrm{P} 4$ production by the $\mathrm{CL}$ and the rate of $\mathrm{P} 4$ metabolism, mainly by the liver. Production of P4 is mainly regulated by the number of large luteal cells (LLC) and constitutive production of $\mathrm{P} 4$ by these cells which in turn is dependent on the provision of sufficient cholesterol substrate, mainly in the form of high-density lipoprotein (HDL). Increasing the number of granulosa cells and thereby the number of LLC, by ovulation of larger or multiple follicles, results in increased P4 output by the CL. Circulating HDL may be manipulated 
by diet and this has been used as a strategy to increase P4 (Cordeiro et al., 2015). Metabolism of P4 is primarily related to the rate of blood flow to the liver (Sangsritavong et al., 2002) and is affected by the physiological condition of the cow. Therefore, practical strategies aimed at changing inherent CL capacity through genetic selection (Cummins et al., 2012; Butler, 2013; Moore et al., 2014) or the manipulation of circulating concentrations of $\mathrm{P} 4$ will be most productive by focussing on increasing luteal tissue volume to increase P4 production and/or limiting P4 metabolism (Wiltbank et al., 2014).

In a study in which inseminated cows were blood sampled on week 5 of presumed pregnancy, 50\% of cows with P4 $<2.8 \mathrm{ng} / \mathrm{ml}$ aborted before week 9 of gestation and $95 \%$ of cows with $\mathrm{P} 4$ of $6.0 \mathrm{ng} / \mathrm{ml}$ on week 5 maintained pregnancy (Starbuck et al., 2004). Kenyon et al. (2013) determined P4 concentration from days 4 to 28 relative to presumptive estrus necessary for maintenance of pregnancy in lactating Holstein cows An early rise in $\mathrm{P} 4$ from day 0 to 14 was associated with establishment of pregnancy after embryo transfer. Cows with $\mathrm{P} 4$ concentration $<5 \mathrm{ng} / \mathrm{ml}$ on day 14 were more likely to lose pregnancy from day 28 to 63 . Faster rise in P4 concentration during the metestrus and early diestrus are associated with pregnancy establishment following embryo transfer, which suggests that early rise in P4 concentration has an indirect effect on embryo development through modulation of uterine environment and secretion of histotroph. Furthermore, the positive effects of early rise in $\mathrm{P} 4$ concentration appear to go beyond the phase of maternal recognition of pregnancy through adhesion and placentation stages.

Given the importance of P4 for pregnancy establishment and the known effects on uterine receptivity and conceptus development many researchers have attempted to manipulate $\mathrm{P} 4$ using a variety of strategies in the days immediately postconception in order to improve conception rates. Clearly, increasing concentrations of $\mathrm{P} 4$ after ovulation stimulates conceptus elongation in beef heifers, dairy cows, and sheep. However, supplementation of cattle with P4 during early pregnancy has resulted in mixed outcomes in terms of embryonic survival (Beltman et al., 2009a; Parr et al., 2014).

Based on the demonstration that elevated P4 accelerates conceptus development and that larger conceptuses produce more IFNT, one could reasonably hypothesize that such advanced conceptuses would be more likely to establish pregnancy. However, data on the impact of post insemination supplementation of P4 on pregnancy rate are conflicting and, at best, indicate a modest positive response. For example, in one recent large study, Nascimento et al. (2013) reported the results of 2 separate analyses that evaluated the effect of hCG treatment post-AI on fertility in lactating dairy cows. The first study was a meta-analysis of 10 different published studies that used hCG treatment on days 4 to 9 post-AI in lactating dairy cows. Overall, hCG administration increased pregnancies per artificial insemination $(\mathrm{P} / \mathrm{AI})$ by 3 percentage points $[34 \%$ $(752 / 2,213)$ vs. $37 \%(808 / 2,184)]$. In a subsequent field trial, lactating Holstein cows $(n=2,979)$ from 6 commercial dairy herds received hCG or not on day 5 after a timed AI Pregnancies per AI were greater in cows treated with hCG $(40.8 \%)$ than control $(37.3 \%)$ cows. Interestingly, the positive effect of hCG (overall approximately $3.5 \%$ ) was restricted to first-lactation cows.

A variety of strategies can be used to increase peripheral P4, ranging from those that stimulate endogenous production such as: (i) manipulation of follicular development to increase the size of the preovulatory follicle and hence the CL (Baruselli et al., 2012; Mesquita et al., 2014; Ramos et al., 2015); (ii) direct stimulation of CL development with luteotrophic agents (Maillo et al., 2014); (iii) induction of accessory CL using appropriately timed administration of $\mathrm{GnRH}$ or hCG (Santos et al., 2001; Stevenson et al., 2007; De Rensis et al., 2010; Lonergan, 2011; Torres et al., 2013); or (iv) direct supplementation with exogenous P4 through injections (Garrett et al., 1988b; Geisert et al., 1991; Pugliesi et al., 2014) or P4-containing devices (Stevenson et al., 2007; Carter et al., 2008; O'Hara et al., 2014b, c).

Paradoxically, depending on the timing of administration, exogenous $\mathrm{P} 4$ can have a negative effect on CL lifespan resulting in short inter-oestrous periods due to premature CL regression (Ginther, 1970; Garrett et al., 1988a; Burke et al., 1994) while at the same time advancing conceptus development due to the changes induced in the endometrium (O'Hara et al., 2014a). This situation is clearly not compatible with successful maintenance of pregnancy. It is possible that a combination of exogenous $\mathrm{P} 4$, to induce the required stimulation of the endometrium and conceptus, and luteotrophic support, such as that provided by hCG, to avoid early CL regression, would provide a means of optimizing maternal recognition of pregnancy. Indeed, administration of hCG at the time of $\mathrm{P} 4$ injections on days 1 to 4 overcame the negative effect on CL lifespan (Ginther, 1970). In support of this notion, in a recent study (O'Hara et al., 2014b), administration of eCG, a glycoprotein secreted by the endometrial cups of pregnant mares with a relatively long half-life of about 2-3 days and with both LH- and FSH-like properties in cattle, to beef heifers on day 3 post oestrus in association with an intravaginal P4 insert reduced the number of short cycles and increased mean luteal tissue weight and circulating P4. However, the numbers of heifers involved was small.

We have recently shown that a single i.m. injection of hCG as early as day 2 or day 3 after oestrus resulted in a larger CL and increased circulating concentrations of P4 compared to controls (Maillo et al., 2014). However, the results of Souza et al. (2015) examining the effect of administration of long-acting injectable P4 (LAP4) and/or hCG on luteal function and conception rate of high producing dairy cows $(n=982)$ would suggest that this does not translate into improved pregnancy rates. Cows were assigned to one of four groups: (i) control; (ii) $900 \mathrm{mg} \mathrm{LAP} 4$; (iii) $2000 \mathrm{IU}$ hCG; (iv) a combination of LAP4 and hCG. While treatments resulted in elevated $\mathrm{P} 4$, conception rate after 
30 days was higher in the LAP4 group, but not in the hCG or LAP4 + hCG groups. Conception rates at 60 days, as well as pregnancy loss between 30 and 60 days after TAI were not affected by treatment.

\section{Final remarks}

One consistent observation from the multiple embryo transfer studies we have carried out, involving the transfer of 10-20 day 7 blastocysts to the uterus of synchronized recipients and recovery on day 14 , is the variation in conceptus size on day 14, even amongst those recovered from the same uterus. Such differences in conceptus length on the same day of gestation may be related to an inherent lack of developmental competency or may simply be a consequence of asynchrony with the maternal environment. It would suggest that factors intrinsic to the blastocysts transferred regulate development, at least in part, and would be consistent with the hypothesis that the quality of the oocyte regulates developmental competence (Rizos et al., 2002).

Our current studies are aiming to understand the underlying factors that regulate conceptus elongation and to attempt to separate those intrinsic to the conceptus from those intrinsic to the uterus. In this regard, Barnwell et al. (2016) recently characterized differential patterns of mRNA expression between short and long bovine conceptuses recovered on day 15 of gestation which may be indicative of conceptus survival.

\section{Acknowledgments}

The work of the authors described here was provided, in part, by grants from Science Foundation Ireland (07/SRC/B1156, 10/IN.1/B3011 and 13/IA/1983) and AFRI competitive grants 2009-01722 and 2012-67015-30173 from the USDA National Institute of Food and Agriculture and R01 HD072898 from the Eunice Kennedy Shriver National Institute of Child Health and Human Development.

\section{References}

Alexopoulos NI, Vajta G, Maddox-Hyttel P, French AJ, Trounson AO. 2005. Stereomicroscopic and histological examination of bovine embryos following extended in vitro culture. Reprod Fertil Dev, 17:799808.

Barnwell CV, Farin PW, Whisnant CS, Alexander JE, Farin CE. 2015. Maternal serum progesterone concentration and early conceptus development of bovine embryos produced in vivo or in vitro. Domest Anim Endocrinol, 52:75-81.

Barnwell CV, Farin PW, Ashwell CM, Farmer WT, Galphin SP Jr, Farin CE. 2016. Differences in mRNA populations of short and long bovine conceptuses on day 15 of gestation. Mol Reprod Dev, 83:424-441.

Baruselli PS, Sa Filho MF, Ferreira RM, Sales JN, Gimenes LU, Vieira LM, Mendanha MF, Bo GA. 2012. Manipulation of follicle development to ensure optimal oocyte quality and conception rates in cattle. Reprod Domest Anim, 47(suppl. 4):134-141.

Bauersachs S, Ulbrich SE, Reichenbach HD, Reichenbach M, Buttner M, Meyer HH, Spencer TE, Minten M, Sax G, Winter G, Wolf E. 2012. Comparison of the effects of early pregnancy with human interferon, alpha 2 (IFNA2), on gene expression in bovine endometrium. Biol Reprod, 86:46.

Bazer FW. 1975. Uterine protein secretions: relationship to development of the conceptus. J Anim Sci, 41:1376-1382.

Bazer FW, Wu G, Spencer TE, Johnson GA, Burghardt RC, Bayless K. 2010. Novel pathways for implantation and establishment and maintenance of pregnancy in mammals. Mol Hum Reprod, 16:135-152.

Bazer FW, Song G, Kim J, Erikson DW, Johnson GA, Burghardt RC, Gao H, Satterfield MC, Spencer TE, Wu G. 2012. Mechanistic mammalian target of rapamycin (MTOR) cell signaling: effects of select nutrients and secreted phosphoprotein 1 on development of mammalian conceptuses. Mol Cell Endocrinol, 354:22-33.

Beltman ME, Lonergan P, Diskin MG, Roche JF, Crowe MA. 2009a. Effect of progesterone supplementation in the first week post conception on embryo survival in beef heifers. Theriogenology, 71:1173-1179.

Beltman ME, Roche JF, Lonergan P, Forde N Crowe MA. 2009b. Evaluation of models to induce low progesterone during the early luteal phase in cattle. Theriogenology, 72:986-992.

Betteridge KJ, Eaglesome MD, Randall GC, Mitchell D. 1980. Collection, description and transfer of embryos from cattle 10--16 days after oestrus. J Reprod Fertil, 59:205-216.

Binelli M, Scolari SC, Pugliesi G, Van Hoeck V, Gonella-Diaza AM, Andrade SC, Gasparin GR, Coutinho LL. 2015. The transcriptome signature of the receptive bovine uterus determined at early gestation. PLoS One, 10:e0122874.

Brandão DO, Maddox-Hyttel P, Lovendahl P, Rumpf R, Stringfellow D, Callesen H. 2004. Post hatching development: a novel system for extended in vitro culture of bovine embryos. Biol Reprod, 71:20482055.

Brooks K, Burns G, Spencer TE. 2014. Conceptus elongation in ruminants: roles of progesterone, prostaglandin, interferon tau and cortisol. J Anim Sci Biotechnol, 5:53.

Burke CR, Mihm M, Macmillan KL, Roche JF. 1994. Some effects of prematurely elevated concentrations of progesterone on luteal and follicular characteristics during the oestrous cycle in heifers. Anim Reprod Sci, 35:27-39.

Burns G, Brooks K, Wildung M, Navakanitworakul R, Christenson LK, Spencer TE. 2014. Extracellular vesicles in luminal fluid of the ovine uterus. PLoS One, 9:e90913.

Butler ST. 2013. Genetic control of reproduction in dairy cows. Reprod Fertil Dev, 26:1-11.

Carter F, Forde N, Duffy P, Wade M, Fair T, Crowe MA, Evans AC, Kenny DA, Roche JF, Lonergan P. 
2008. Effect of increasing progesterone concentration from day 3 of pregnancy on subsequent embryo survival and development in beef heifers. Reprod Fertil Dev, 20:368-375.

Carter F, Rings F, Mamo S, Holker M, Kuzmany A, Besenfelder U, Havlicek V, Mehta JP, Tesfaye D, Schellander K, Lonergan P. 2010. Effect of elevated circulating progesterone concentration on bovine blastocyst development and global transcriptome following endoscopic transfer of in vitro produced embryos to the bovine oviduct. Biol Reprod, 83:707719.

Clemente M, de La Fuente J, Fair T, Al Naib A, Gutierrez-Adan A, Roche JF, Rizos D, Lonergan P. 2009. Progesterone and conceptus elongation in cattle: a direct effect on the embryo or an indirect effect via the endometrium? Reproduction, 138:507-517.

Cordeiro MB, Peres MS, de Souza JM, Gaspar P, Barbiere F, Sa Filho MF, Filho MM, Dinardi RN, Nogueira GP, Mesquita FS, Pugliesi G, Martins T, Binelli M, Membrive CM. 2015. Supplementation with sunflower seed increases circulating cholesterol concentrations and potentially impacts on the pregnancy rates in Bos indicus beef cattle. Theriogenology, $83: 1461-1468$.

Cummins SB, Lonergan P, Evans AC, Butler ST 2012. Genetic merit for fertility traits in Holstein cows II. Ovarian follicular and corpus luteum dynamics, reproductive hormones, and estrus behavior. J Dairy Sci, 95:3698-710.

De Rensis F, Lopez-Gatius F, Garcia-Ispierto I, Techakumpu M. 2010. Clinical use of human chorionic gonadotropin in dairy cows: an update. Theriogenology, 73:1001-1008.

Diskin MG, Murphy JJ, Sreenan JM. 2006. Embryo survival in dairy cows managed under pastoral conditions. Anim Reprod Sci, 96:297-311.

Diskin MG, Morris DG. 2008. Embryonic and early foetal losses in cattle and other ruminants. Reprod Domest Anim, 43(suppl. 2):260-267

Donaldson LE. 1985. Matching of embryo stages and grades with recipient oestrous synchrony in bovine embryo transfer. Vet Rec, 117:489-91.

Dorniak P, Bazer FW, Spencer TE. 2011. Prostaglandins regulate conceptus elongation and mediate effects of interferon tau on the ovine uterine endometrium. Biol Reprod, 84:1119-1127.

Dorniak P, Bazer FW, Wu G, Spencer TE. 2012 Conceptus-derived prostaglandins regulate endometrial function in sheep. Biol Reprod, 87:9,1-7.

Dorniak P, Bazer FW, Spencer TE. 2013. Physiology and Endocrinology Symposium: biological role of interferon tau in endometrial function and conceptus elongation. J Anim Sci, 91:1627-1638.

Faulkner S, Elia G, O'Boyle P, Dunn M, Morris D. 2013. Composition of the bovine uterine proteome is associated with stage of cycle and concentration of systemic progesterone. Proteomics, 13:3333-3353.

Ferguson CE, Davidson TR, Mello MRB, Lima AS, Kesler DJ, Wheeler MB, Godke RA. 2005. Evidence for a direct effect of P4 on IVF-derived bovine 8-cell embryos. Reprod Fertil Dev, 17:219.
Ferguson CE, Kesler DJ, Godke RA. 2011. Progesterone enhances in vitro development of bovine embryos. Theriogenology, 77:108-114.

Flechon JE, Guillomot M, Charlier M, Flechon B, Martal J. 1986. Experimental studies on the elongation of the ewe blastocyst. Reprod Nutr Dev, 26:1017-1024.

Forde N, Carter F, Fair T, Crowe MA, Evans AC, Spencer TE, Bazer FW, McBride R, Boland MP, O'Gaora P, Lonergan P, Roche JF. 2009. Progesterone-regulated changes in endometrial gene expression contribute to advanced conceptus development in cattle. Biol Reprod, 81:784-794.

Forde N, Beltman ME, Duffy GB, Duffy P, Mehta JP, O'Gaora P, Roche JF, Lonergan P, Crowe MA 2011a. Changes in the endometrial transcriptome during the bovine estrous cycle: effect of low circulating progesterone and consequences for conceptus elongation. Biol Reprod, 84:266-278.

Forde N, Carter F, Spencer TE, Bazer FW, Sandra O, Mansouri-Attia N, Okumu LA, McGettigan PA, Mehta JP, McBride R, O'Gaora P, Roche JF, Lonergan P. 2011b. Conceptus-induced changes in the endometrial transcriptome: how soon does the cow know she is pregnant? Biol Reprod, 85:144-156.

Forde N, Mehta JP, Minten M, Crowe MA, Roche JF, Spencer TE, Lonergan P. 2012. Effects of low progesterone on the endometrial transcriptome in cattle. Biol Reprod, 87:124.

Forde N, McGettigan PA, Mehta JP, O'Hara L, Mamo S, Bazer FW, Spencer TE, Lonergan $P$. 2014a. Proteomic analysis of uterine fluid during the pre-implantation period of pregnancy in cattle. Reproduction, 147:575-587.

Forde N, Simintiras CA, Sturmey R, Mamo S, Kelly AK, Spencer TE, Bazer FW, Lonergan P. 2014 b. Amino acids in the uterine luminal fluid reflects the temporal changes in transporter expression in the endometrium and conceptus during early pregnancy in cattle. PLoS One, 9:e100010.

Forde N, Bazer FW, Spencer TE, Lonergan P. 2015. 'Conceptualizing' the Endometrium: iIdentification of conceptus-derived proteins during early pregnancy in cattle. Biol Reprod, 92:156.

Frade MC, Frade C, Cordeiro MB, Sá Filho MF, Mesquita FS, Nogueira Gde P, Binelli M, Membrive CM. 2014. Manifestation of estrous behavior and subsequent progesterone concentration at timed-embryo transfer in cattle are positively associated with pregnancy success of recipients. Anim Reprod Sci, 151:85-90.

Garrett JE, Geisert RD, Zavy MT, Gries LK, Wettemann RP, Buchanan DS. 1988a. Effect of exogenous progesterone on prostaglandin F2 alpha release and the interestrous interval in the bovine. Prostaglandins, 36:85-96.

Garrett JE, Geisert RD, Zavy MT, Morgan GL. 1988b. Evidence for maternal regulation of early conceptus growth and development in beef cattle. $J$ Reprod Fertil, 84:437-446.

Geisert RD, Fox TC, Morgan GL, Wells ME, Wettemann RP, Zavy MT. 1991. Survival of bovine embryos transferred to progesterone-treated 
asynchronous recipients. $J$ Reprod Fertil, 92:475-482.

Ginther OJ. 1970. Effect of progesterone on length of estrous cycle in cattle. Am J Vet Res, 31:493-496.

Goff AK, Smith LC. 1998. Effect of steroid treatment of endometrial cells on blastocyst development during co-culture. Theriogenology, 49:1021-1030.

Gray CA, Bartol FF, Tarleton BJ, Wiley AA, Johnson GA, Bazer FW, Spencer TE. 2001. Developmental biology of uterine glands. Biol Reprod, 65:1311-1323.

Gray CA, Burghardt RC, Johnson GA, Bazer FW, Spencer TE. 2002. Evidence that absence of endometrial gland secretions in uterine gland knockout ewes compromises conceptus survival and elongation. Reproduction, 124:289-300.

Guillomot M. 1995. Cellular interactions during implantation in domestic ruminants. J Reprod Fertil Suppl, 49:39-51.

Hasler JF, Mccauley AD, Lathrop WF, Foote RH. 1987. Effect of donor-embryo-recipient interactions on pregnancy rate in a large-scale bovine embryo transfer program. Theriogenology, 27:139-168.

Hasler JF. 2001. Factors affecting frozen and fresh embryo transfer pregnancy rates in cattle Theriogenology, 56:1401-1415.

Heyman Y. 1988. Moment de la transplantation et succes de la gestation chez les mammiferes. Reprod Nutr Dev, 28:1773-1780.

Hue I, Degrelle SA, Turenne N. 2012. Conceptus elongation in cattle: genes, models and questions. Anim Reprod Sci, 134:19-28.

Kenyon AG, Mendonca LG, Lopes G, Jr, Lima JR, Santos JE, Chebel RC. 2013. Minimal progesterone concentration required for embryo survival after embryo transfer in lactating Holstein cows. Anim Reprod Sci, 136:223-230.

Kerbler TL, Buhr MM, Jordan LT, Leslie KE, Walton JS. 1997. Relationship between maternal plasma progesterone concentration and interferon-tau synthesis by the conceptus in cattle. Theriogenology, 47:703-714.

Larson JE, Krisher RL, Lamb GC. 2011. Effects of supplemental progesterone on the development, metabolism and blastocyst cell number of bovine embryos produced in vitro. Reprod Fertil Dev, 23:311318

Lawson RA, Cahill LP. 1983. Modification of the embryo-maternal relationship in ewes by progesterone treatment early in the oestrous cycle. $J$ Reprod Fertil, 67:473-475

Ledgard AM, Berg MC, McMillan WH, Smolenski G, Peterson AJ. 2012. Effect of asynchronous transfer on bovine embryonic development and relationship with early cycle uterine proteome profiles. Reprod Fertil Dev, 24:962-972.

Lonergan P. 2011. Influence of progesterone on oocyte quality and embryo development in cows. Theriogenology, 76:1594-1601.

Lonergan P, Forde N. 2014. Maternal-embryo interaction leading up to the initiation of implantation in cattle. Animal, 8(suppl. 1):64-69.

Lonergan P. 2015. New insights into the function of progesterone in early pregnancy. Anim Front, 5: 12-17. Maillo V, Duffy P, O'Hara L, de Frutos C, Kelly AK, Lonergan P, Rizos D. 2014. Effect of hCG administration during corpus luteum establishment on subsequent corpus luteum development and circulating progesterone concentrations in beef heifers. Reprod Fertil Dev, 26:367-374.

Mamo S, Mehta JP, McGettigan P, Fair T, Spencer TE, Bazer FW, Lonergan P. 2011. RNA sequencing reveals gene clusters in bovine conceptuses associated with maternal recognition of pregnancy and implantation. Biol Reprod, 85:1143-1151.

Merlo B, Iacono E, Mari G. 2007. Effect of progesterone and epidermal growth factor on in vitroproduced eight-cell bovine embryos in a serum-free culture medium. Reprod Fertil Dev, 19:211.

Mesquita FS, Pugliesi G, Scolari SC, França MR, Ramos RS, Oliveira M, Papa PC, Bressan FF, Meirelles FV, Silva LA, Nogueira GP, Membrive CM, Binelli M. 2014. Manipulation of the periovulatory sex steroidal milieu affects endometrial but not luteal gene expression in early diestrus Nelore cows. Theriogenology, 81:861-869.

Moore NW, Shelton JN. 1964. Egg transfer in sheep. Effect of degree of synchronization between donor and recipient, age of egg, and site of transfer on the survival of transferred eggs. J Reprod Fertil, 7:145-152.

Moore, SG, Scully S, Browne JA, Fair T, Butler ST. 2014. Genetic merit for fertility traits in Holstein cows: V. Factors affecting circulating progesterone concentrations. J Dairy Sci, 97:5543-5557.

Nascimento AB, Bender RW, Souza AH, Ayres H, Araujo RR, Guenther JN, Sartori R, Wiltbank MC. 2013. Effect of treatment with human chorionic gonadotropin on day 5 after timed artificial insemination on fertility of lactating dairy cows. J Dairy Sci, 96:2873-2882

O'Hara L, Scully S, Maillo V, Kelly AK, Duffy P, Carter F, Forde N, Rizos D, Lonergan P. 2012. Effect of follicular aspiration just before ovulation on corpus luteum characteristics, circulating progesterone concentrations and uterine receptivity in singleovulating and superstimulated heifers. Reproduction, 143:673-682.

O'Hara L, Forde N, Carter F, Rizos D, Maillo V, Ealy AD, Kelly AK, Rodriguez P, Isaka N, Evans AC, Lonergan P. 2014a. Paradoxical effect of supplementary progesterone between day 3 and day 7 on corpus luteum function and conceptus development in cattle. Reprod Fertil Dev, 26:328-336.

O'Hara L, Forde N, Duffy P, Randi F, Kelly AK, Valenza A, Rodriguez P, Lonergan P. 2014b. Effect of combined exogenous progesterone with luteotrophic support via equine chorionic gonadotrophin (eCG) on corpus luteum development, circulating progesterone concentrations and embryo development in cattle. Reprod Fertil Dev, 28:269-277.

O'Hara L, Forde N, Kelly AK, Lonergan P. 2014c. Effect of bovine blastocyst size at embryo transfer on day 7 on conceptus length on day 14: can supplementary progesterone rescue small embryos? Theriogenology, 81:1123-1128. 
Okumu LA, Forde N, Fahey AG, Fitzpatrick E, Roche JF, Crowe MA, Lonergan P. 2010. The effect of elevated progesterone and pregnancy status on mRNA expression and localisation of progesterone and oestrogen receptors in the bovine uterus. Reproduction, 140:143-153.

Parr MH, Mullen MP, Crowe MA, Roche JF, Lonergan P, Evans ACO, Diskin MG. 2012. Relationship between pregnancy per artificial insemination and early luteal concentrations of progesterone and establishment of repeatability estimates for these traits in Holstein-Friesian heifers. $J$ Dairy Sci, 95:2390-2396.

Parr MH, Crowe MA, Lonergan P, Evans AC, Rizos D, Diskin MG. 2014. Effect of exogenous progesterone supplementation in the early luteal phase postinsemination on pregnancy per artificial insemination in Holstein-Friesian cows. Anim Reprod Sci, 150:7-14.

Pope WF. 1988. Uterine asynchrony: a cause of embryonic loss. Biol Reprod, 39:999-1003.

Pugliesi G, Oliveria ML, Scolari SC, Lopes E, Pinaffi FV, Miagawa BT, Paiva YN, Maio JR, Nogueira GP, Binelli M. 2014. Corpus luteum development and function after supplementation of long-acting progesterone during the early luteal phase in beef cattle. Reprod Domest Anim, 49:85-91.

Ramos RS, Oliveira ML, Izaguirry AP, Vargas LM, Soares MB, Mesquita FS, Santos FW, Binelli M. 2015. The periovulatory endocrine milieu affects the uterine redox environment in beef cows. Reprod Biol Endocrinol, 13:39.

Randi F, Fernandez-Fuertes B, McDonald M, Forde N, Kelly AK, Amorin HB, Lima EM, Morotti F, Seneda MM, Lonergan P. 2015. Asynchronous embryo transfer as a tool to understand embryo uterine interaction in cattle: Is a large conceptus a good thing? Reprod Fertil Dev. doi: 10.1071/RD15195

Reggio BC, Lynn JW, Godke RA. 1997. The effect of progesterone on the development of IVF-derived bovine embryos cultured in a semi-defined culture medium. Theriogenology, 47:284.

Ribeiro ES, Greco LF, Bisinotto RS, Lima FS, Thatcher WW, Santos JE. 2016a. Biology of preimplantation conceptus at the onset of elongation in dairy cows. Biol Reprod, 94:97.

Ribeiro ES, Monteiro AP, Bisinotto RS, Lima FS, Greco LF, Ealy AD, Thatcher WW, Santos JE. 2016b. Conceptus development and transcriptome at preimplantation stages in lactating dairy cows of distinct genetic groups and estrous cyclic statuses. J Dairy Sci, 99:4761-4777.

Rizos D, Ward F, Duffy, P, Boland MP, Lonergan P. 2002. Consequences of bovine oocyte maturation, fertilization or early embryo development in vitro versus in vivo: implications for blastocyst yield and blastocyst quality. Mol Reprod Dev, 61:234-248.

Rizos D, Scully S, Kelly AK, Ealy AD, Moros R, Duffy P, Al Naib A, Forde N, Lonergan P. 2012. Effects of human chorionic gonadotrophin administration on day 5 after oestrus on corpus luteum characteristics, circulating progesterone and conceptus elongation in cattle. Reprod Fertil Dev, 24:472-481.
Rodrigues CA, Mancilha RF, Dalalio M, Reis EL, Nichi M, Madureira EH, Baruselli PS. 2003. Aumento da axa de concepção em receptoras de embriões FIV tratadas com GnRH no momento da inovulação. Acta Sci Vet, 550-551.

Rowson LE, Moor RM. 1966. Embryo transfer in the sheep: the significance of synchronizing oestrus in the donor and recipient animal. J Reprod Fertil, 11:207212.

Rowson LE, Lawson RA, Moor RM, Baker AA. 1972. Egg transfer in the cow: synchronization requirements. J Reprod Fertil, 28:427-431

Sandra O, Mansouri-Attia N, Lea RG. 2011. Novel aspects of endometrial function: a biological sensor of embryo quality and driver of pregnancy success. Reprod Fertil Dev, 24:68-79.

Sangsritavong S, Combs DK, Sartori R, Armentano LE, Wiltbank MC. 2002. High feed intake increases liver blood flow and metabolism of progesterone and estradiol-17beta in dairy cattle. $J$ Dairy Sci, 85:28312842.

Santos JE, Thatcher WW, Pool L, Overton MW. 2001. Effect of human chorionic gonadotropin on luteal function and reproductive performance of highproducing lactating Holstein dairy cows. J Anim Sci, 79:2881-2894

Satterfield MC, Bazer FW, Spencer TE. 2006. Progesterone regulation of preimplantation conceptus growth and galectin 15 (LGALS15) in the ovine uterus. Biol Reprod, 75:289-296.

Souza EDF. 2015. Effect of long-acting injectable progesterone in luteal function and conception rate of high producing Holstein cows submitted to timed artificial insemination [in portuguese]. São Paulo, SP: University of São Paulo, Faculdade de Medicina Veterinária e Zootecnia. Brazil. Masters Thesis.

Spencer TE, Gray CA. 2006. Sheep uterine gland knockout (UGKO) model. Methods Mol Med, 121:8594.

Spencer TE, Sandra O, Wolf E. 2008. Genes involved in conceptus-endometrial interactions in ruminants: insights from reductionism and thoughts on holistic approaches. Reproduction, 135:165-179.

Spencer TE, Forde N, Dorniak P, Hansen TR, Romero JJ, Lonergan P. 2013. Conceptus-derived prostaglandins regulate gene expression in the endometrium prior to pregnancy recognition in ruminants. Reproduction, 146:377-387.

Spencer TE, Forde N, Lonergan P. 2015. The role of progesterone and conceptus-derived factors in uterine biology during early pregnancy in ruminants. J Dairy Sci, 99:5941-5950.

Starbuck MJ, Dailey R, Inskeep EK. 2004. Factors affecting retention of early pregnancy in dairy cattle. Anim Reprod Sci, 84:27-39.

Stevenson JS, Portaluppi MA, Tenhouse DE, Lloyd A, Eborn DR, Kacuba S, DeJarnette JM. 2007. Interventions after artificial insemination: conception rates, pregnancy survival, and ovarian responses to gonadotropin-releasing hormone, human chorionic gonadotropin, and progesterone. J Dairy Sci, 90:331340 . 
Stronge AJ, Sreenan JM, Diskin MG, Mee JF, Kenny DA, Morris DG. 2005. Post-insemination milk progesterone concentration and embryo survival in dairy cows. Theriogenology, 64:1212-1224.

Torres A, Chagas e Silva J, Deloche MC, Humblot P, Horta AE, Lopes-da-Costa L. 2013. Secondary corpora lutea induced by $\mathrm{HCG}$ treatment enhanced demi-embryo survival in lactating high-yielding dairy cows. Reprod Domest Anim, 48:643-650.

Valour D, Degrelle SA, Ponter AA, Giraud-Delville C, Campion E, Guyader-Joly C, Richard C, Constant F, Humblot P, Ponsart C, Hue I, Grimard B. 2014. Energy and lipid metabolism gene expression of D18 embryos in dairy cows is related to dam physiological status. Physiol Genomics, 46:39-56.

Wilmut I, Sales DI. 1981. Effect of an asynchronous environment on embryonic development in sheep. $J$ Reprod Fertil, 61:179-184.
Wiltbank MC, Souza AH, Carvalho PD, Cunha AP, Giordano JO, Fricke PM, Baez GM, Diskin MG. 2014. Physiological and practical effects of progesterone on reproduction in dairy cattle. Animal, 8(suppl. 1):70-81.

Wiltbank MC, Baez GM, Garcia-Guerra A, Toledo MZ, Monteiro PL, Melo LF, Ochoa JC, Santos JE, Sartori R. 2016. Pivotal periods for pregnancy loss during the first trimester of gestation in lactating dairy cows. Theriogenology, 86:239-253.

Wright JM. 1981. Non-surgical embryo transfer in cattle embryo-recipient interactions. Theriogenology, 15:43-56.

Zhao S, Liu ZX, Gao H, Wu Y, Fang Y, Wu SS, Li MJ, Bai JH, Liu Y, Evans A, Zeng SM. 2015. A three-dimensional culture system using alginate hydrogel prolongs hatched cattle embryo development in vitro. Theriogenology, 84:184-92. 